\title{
PEMILIHAN PEGAWAI BERPRESTASI DI LINGKUNGAN YAYASAN TP 45 NEGARA BERBASIS SISTEM PENUNJANG KEPUTUSAN DENGAN METODE SIMPLE ADDITIVE WEIGHTING
}

\author{
I Nengah Juniawan ${ }^{1}$ \\ Ida Bagus Kade Dwi Suta Negara ${ }^{2}$ \\ Universitas Triatma Mulya, Jembrana ${ }^{1,2}$ \\ email: juniawan@triatmamulya.ac.id
}

\begin{abstract}
The quality of human resources is one of the supporting factors to improve the productivity of the performance of an agency or organization. Therefore, competent human resources can support the level of performance, with the performance appraisal will be known that the achievements of each employee, this makes it easy for agencies or organizations to consider in determining the best employees. Decision Support System is a system that is able to manage data and provide the best alternative solutions. The selection of outstanding employees is determined based on criteria and weights, namely: the level of attendance, accuracy of work assignments, leadership, and length of service. Furthermore, the data from the employee is processed using the Simple Additive Weighting (SAW) method. This Simple Additive Weighting ( $S A W$ ) method gives a weighting to each of the criteria used to produce the best alternative value. With this system, it is expected to be able to assist in faster decision making in high achieving employees within the TP 45 Negara Foundation.
\end{abstract}

Keywords: $\quad$ outstanding employees, SPK, SAW.

\section{PENDAHULUAN}

Teknologi informasi semakin berkembang dalam segala aspek kehidupan manusia yang dapat mempermudah pekerjaan manusia itu sendiri. Kualitas sumber daya manusia merupakan salah satu faktor penunjang untuk meningkatkan produktivitas kinerja suatu instansi atau organisasi. Oleh sebab dari itu sumber daya manusia yang kompeten dapat mendukung tingkat kinerja, dengan penilaian kinerja akan diketahui prestasi yang dicapai setiap pegawai, hal ini memudahkan instansi atau organisasi untuk pertimbangan dalam menentukan karyawan terbaik.

Manusia dalam kehidupan sehari-hari sering menemui masalah dalam pengambilan keputusan.
Masalah yang muncul dapat berskala besar atau kecil yang sangat berpengaruh dalam hasil keputusan. Seorang pimpinan benar-benar harus selektif dalam mengambil keputusan untuk pemilihan karyawan terbaiknya. Sekarang pengembangan sistem dapat membantu menentukan alternatif terbaik dalam suatu permasalahan, yaitu sistem penunjang keputusan (SPK). Di dalam sistem pendukung keputusan terdapat alternatif, kriteria dan bobot yang digunakan untuk menentukan suatu solusi terbaik [1].

Sistem Penunjang Keputusan (SPK) adalah sistem yang mampu mengelola data dan memberikan solusi alternatif terbaik. SPK ini dapat membantu pengambilan keputusan 
bagi pihak pengambil keputusan dalam menilai dan menentukan alternatif untuk pemilihan pegawai terbaik secara akurat dan cepat. Untuk mendukung SPK yang efektif, sistem ini akan dibangun berbasis web dimana dapat diakses melalui internet, sehingga pemecahan masalah dan pemberian solusi bisa secara langsung dan cepat.

Dengan permasalahan tersebut, maka diperlukan sebuah sistem penunjang keputusan pemilihan pegawai berprestasi. Dengan sistem ini diharapkan mampu menyajikan informasi yang lebih cepat dan akurat. Metode yang digunakan dalam pemilihan karyawan berprestasi ini adalah Simple Additive Weight (SAW). Dimana metode ini merupakan metode pembilangan terbobot atau metode yang memberikan kriteria-kriteria tertentu yang memiliki bobot nilai masing-masing sehingga dari hasil penjumlahan bobot tersebut akan diperoleh hasil yang menjadi keputusan akhirnya. Penelitian ini diharapkan sebagai salah satu alternatif untuk membantu pengurus yayasan dalam menentukan keputusan terkait pemilihan karyawan terbaik di lingkungan yayasannya.

\section{TINJAUAN PUSTAKA \\ Sistem Penunjang Keputusan}

Sistem penunjang keputusan adalah sekumpulan elemen yang saling berhubungan untuk membentuk suatu kesatuan dalam proses pemilihan berbagai alternatif tindakan guna menyelesaikan suatu masalah, sehingga masalah tersebut dapat diselesaikan secara efektif dan efisien.

Menurut Kusrini, tujuan dari Sistem Penunjang Keputusan adalah [2]:
1. Membantu manajer dalam pengambilan keputusan atas masalah semistruktur

2. Memberikan dukungan atas pertimbangan manajer dan bukannya dimaksudkan untuk menggantikan fungsi manajer

3. Peningkatan produktivitas

4. Berdaya saing

\section{Simple Additive Weight (SAW)}

Metode Simple Additive Weight (SAW), sering juga dikenal dengan istilah metode penjumlahan terbobot. Konsep dasar metode Simple Additive Weight (SAW) adalah mencari penjumlahan terbobot dari rating kinerja pada setiap alternatif pada semua atribut [3].

Perhitungan metode Simple Additive Weight (SAW) dapat ditulis sebagai berikut:

$R_{i j}=\left\{\begin{array}{l}\frac{x_{i j}}{M a x_{i j}} \text { jika } j \text { adalah atribut keuntungan (benefit) } \\ \frac{\operatorname{Min}_{i j}}{x_{i j}} \quad \text { jika j adalah atribut biaya (cost) }\end{array}\right.$

rumus (1)

Dimana :

Rij =Rating kinerja ternormalisasi

Maxij =Nilai maksimum dari setiap baris dan kolom

Minij =Nilai minimum dari setiap baris dan kolom

$\mathrm{Xij}=$ Baris dan kolom dari matriks

Dengan $\mathrm{Rij}$ adalah rating kinerja ternormalisasi dari alternatif $\mathrm{Ai}$ pada atribut $\mathrm{Cj} ; \mathrm{i}=1,2, \ldots \mathrm{m}$ dan $\mathrm{j}=$ $1,2, \ldots, \mathrm{n}$

$$
V_{i}=\sum_{j=1}^{n} w_{j} R_{i j}
$$

rumus (2)

Nilai Vi yang lebih besar mengindikasikan bahwa alternatif $\mathrm{Ai}$ lebih terpilih. 
Dimana :

$\mathrm{Vi} \quad=$ Nilai akhir dari alternatif

$\mathrm{Wi} \quad=$ Bobot yang telah ditentukan

1) $\mathrm{Rij}=$ Normalisasi matriks

\section{METODE PENELITIAN}

Pada penelitian ini, yaitu Pemilihan Pegawai Berprestasi di Lingkungan Yayasan Tp 45 Negara Berbasis Sistem Penunjang Keputusan dengan Metode Simple Additive
Weighting. Sistem penunjang keputusan ini terdiri dari beberapa proses utama yaitu: input data berupa kriteria dan bobot kriteria, input data alternatif, proses set nilai alternatif, proses perhitungan menggunakan metode SAW, dan menampilkan nilai akhir. Adapun tahapan pembuatan SPK ini dapat digambarkan sebagai berikut:

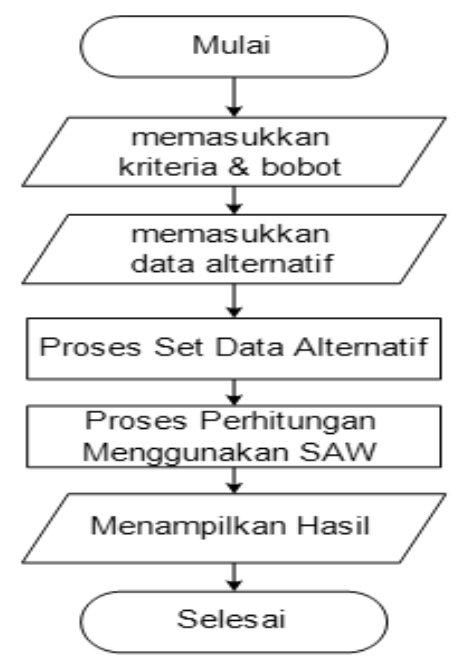

\section{Gambar 1 Tahapan Pemilihan Pegawai Berprestasi Berbasis Sistem Penunjang Keputusan}

Pada tahap awal adalah melakukan inputan data berupa data kriteria dan bobot dari masing-masing kriteria. Selanjutnya adalah proses memasukkan data alternatif berupa data pegawai dan proses set nilai data alternatif. Pada tahapan berikutnya adalah dilakukan normalisasi data sebelum dilakukan perhitungan menggunakan metode Simple Additive Weight ( $S A W)$ menggunakan kriteriakriteria yang telah ditentukan sebelumnya. Hasil akhir nya berupa nilai akhir kriteria yang dihitung pada proses sebelumnya. Nilai akhir tersebut digunakan untuk menentukan rangking pewagai berprestasi.

\section{HASIL DAN PEMBAHASAN}

Pada hasil penelitian ini, penulis memberikan penjelaskan hasil dari penelitian yang dilakukan pada metodologi penelitian. Berikut ini penjelasan dari hasil yang dilakukan pada penelitian ini:

\section{Proses Perhitungan SAW}

Berikut ini adalah perhitungan sistem penunjang keputusan menggunakan metode SAW, yaitu sebagai berikut: 
a. Penentuan Kriteria dan Bobot

Tabel 1 Kriteria Bobot

\begin{tabular}{cccc}
\hline Kode & Kriteria & Bobot & Benefit / Cost \\
\hline K1 & Tingkat Kehadiran & $40 \%$ & Benefit \\
K2 & $\begin{array}{c}\text { Ketepatan Mengerjakan } \\
\text { Tugas }\end{array}$ & $30 \%$ & Benefit \\
& Kepemimpinan & $20 \%$ & Benefit \\
K3 & Lama Masa Kerja & $10 \%$ & Benefit \\
\hline
\end{tabular}

b. Set Alternatif Data

Table 2. Alternatif Data

\begin{tabular}{ccccc}
\hline \multirow{2}{*}{ Data } & \multicolumn{4}{c}{ Kriteria } \\
\cline { 2 - 5 } Alternatif & K1 & K2 & K3 & K4 \\
\hline Juni & 98 & 90 & 85 & 6 \\
Yoga & 97 & 95 & 88 & 4 \\
Ratih & 90 & 89 & 96 & 5 \\
\hline
\end{tabular}

c. Perhitungan dengan SAW

Normalisasi matriks (Rij)

dengan rumus (1) di atas,sehingga

mendapatkan nilai sebagai berikut:

Table 3. Normalisasi Matriks

\begin{tabular}{ccccc}
\hline $\mathrm{R}$ & $\mathrm{j}_{1}$ & $\mathrm{j}_{2}$ & $\mathrm{j}_{3}$ & $\mathrm{j}_{4}$ \\
\hline $\mathrm{i} 1$ & 1,00 & 0,95 & 0,89 & 1,00 \\
$\mathrm{i} 2$ & 0,99 & 1,00 & 0,92 & 0,67 \\
$\mathrm{i} 3$ & 0,92 & 0,94 & 1,00 & 0,83 \\
\hline
\end{tabular}

Berikutnya adalah menghitung nilai vector bobot (Vi) dengan rumus
(2), sehingga mendapatkan hasil sebagai berikut:

Table 4. Vector Bobot (Vi)

\begin{tabular}{cccccc}
\hline $\begin{array}{c}\text { Data } \\
\text { Alternatif }\end{array}$ & $\mathrm{V}_{1}$ & $\mathrm{~V}_{2}$ & $\mathrm{~V}_{3}$ & $\mathrm{~V}_{4}$ & $\mathrm{~V}_{\text {total }}$ \\
\hline Juni & 0,40 & 0,28 & 0,18 & 0,10 & 0,96 \\
Yoga & 0,40 & 0,30 & 0,18 & 0,07 & 0,95 \\
Ratih & 0,37 & 0,28 & 0,20 & 0,08 & 0,93 \\
\hline
\end{tabular}

\section{Implementasi}

a. Halaman Login

Halaman ini terdapat sebuah form yang harus diisi oleh admin. Admin mengisikan Username dan Password sebelum mengakses ke dalam sistem, Halaman Login ditujukan pada Gambar 1. 


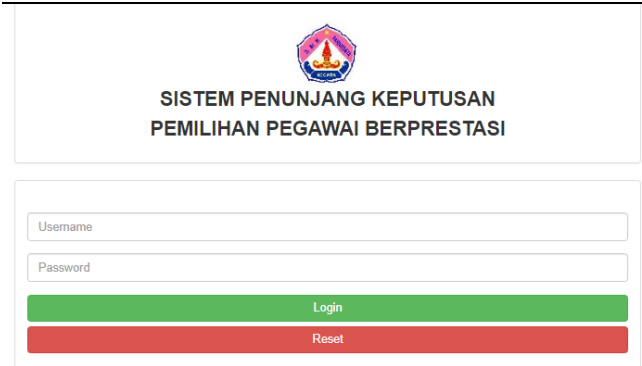

\section{Gambar 1 Halaman Login}

b. Halaman Kriteria dan Bobot

Pada halaman ini terdapat inputan berupa data bobot, yaitu nama bobot, nilai bobot, serta benefit/cost. Halaman kriteria dan bobot dapat dilihat pada Gambar 1.

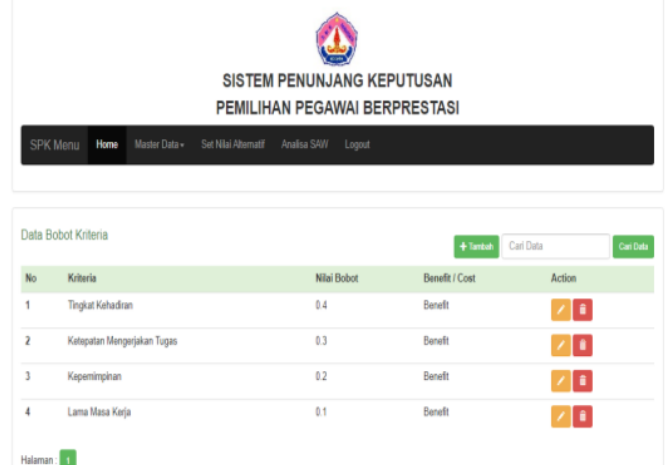

Gambar 2 Halaman Kriteria dan Bobot

\section{c. Halaman Input Data Alternatif}

Pada halaman ini terdapat inputan data berupa data alternatif, dalam penelitian ini adalah data pegawai yayasan TP 45 Negara, halaman ini dapat dilihat pada gambar 3 berikut:

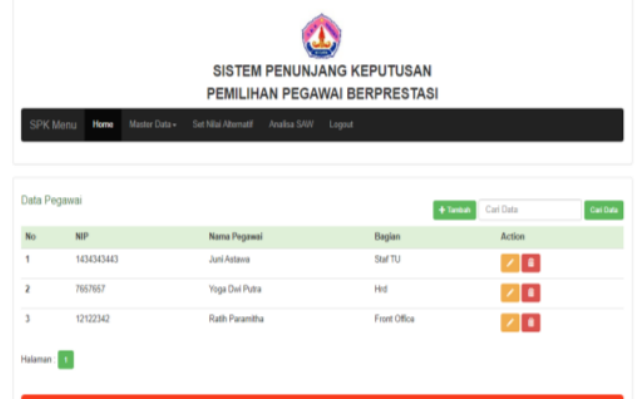

Gambar 3 Halaman Input Dara Alternatif

\section{c. Halaman Set Data Alternatif}

Halaman set data alternatif digunakan untuk menginputkan nilai alternatif untuk masing-masing kriteria, halaman ini dapat dilihat pada Gambar 4 :
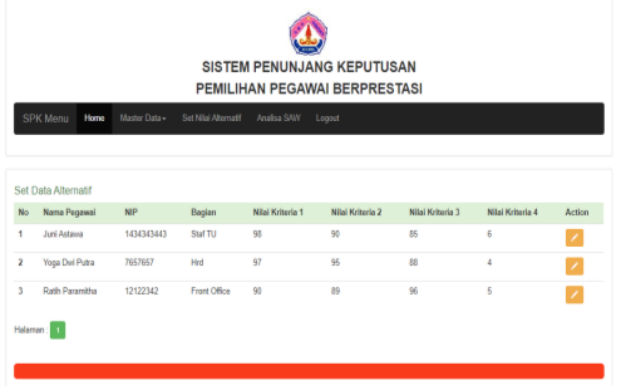

\section{Gambar 4 Halaman Set Data Alternatif}

\section{d. Halaman Analisa SAW}

Halaman analisa SAW ini berisi perhitungan menggunakan metode SAW serta menampilkan hasilnya, halaman ini dapat dilihat pada Gambar 5 berikut ini:
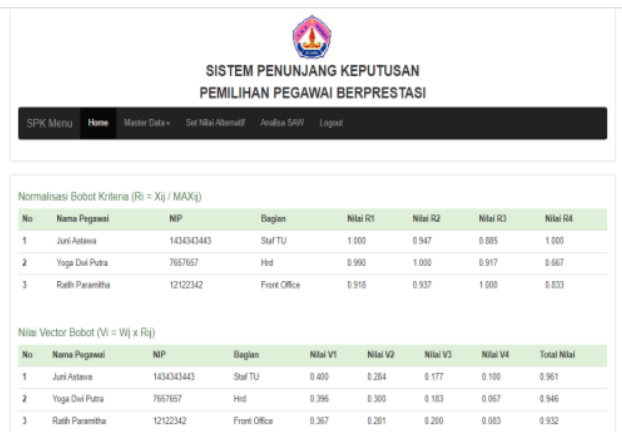

Gambar 5 Halaman Analisa SAW

\section{SIMPULAN DAN SARAN \\ Simpulan}

Dengan adanya sistem ini diharapkan Yayasan TP 45 Negara dalam mengambil keputusan untuk pemilihan pegawai berprestasi sesuai dengan kriteria. Sistem ini terdiri dari beberapa fitur diantaranya: penginputan kriteria dan bobot, penginputan dan set alternatif data, melakukan perhitungan menggunakan metode SAW serta menampilkan hasil. 
Saran

Untuk pengembangan lebih lanjut, adapun saran-saran yang dapat penulis sampaikan adalah sistem ini sebaiknya dilakukan pemeliharaan berkala untuk menjaga dan memaksimalkan fungsi kebutuhan dan informasi yang dibutuhkan oleh Pengurus Yayasan.

\section{DAFTAR PUSTAKA}

K. Umam, V. E. Sulastri, T. Andiri, D.

U. Sutiksno, and Mesran,

"Perancangan Sistem

Pendukung Keputusan

Penentuan Prioritas Produk

Unggulan Daerah

Menggunakan Metode

VIKOR,” J. Ris. Komput., vol.

Vol 5, no. 1, pp. 43-49, 2017.

Kusrini Dan Gole, A W. (2007).

"Sistem Pendukung Keputusan

Penentuan Prestasi Pegawai

Nakertrans Sumba Barat Di

Waikabubak." SNATI 2007.

ISSN: 1907-5022. Hal. D-47 s/d D-52.

Munthe, H.G., " Sistem Pendukung Keputusan Penentuan Prioritas Usulan Sertifikasi Guru Dengan Metode Simple Additive Weighting", Pelita Informatika Budi Darma, Vol IV, No. 2, 2013. 